\title{
As influências das garantias de ficção, literária e de uso na indexação da literatura infantojuvenil: proposta de modelo de leitura
}

\author{
Vesu Alves, Roberta Caroline \\ As influências das garantias de ficção, literária e de uso na indexação da literatura infantojuvenil: \\ proposta de modelo de leitura ${ }^{1}$ \\ Palabra Clave (La Plata), vol. 9, núm. 2, 2020 \\ Universidad Nacional de La Plata, Argentina \\ Disponible en: http://www.redalyc.org/articulo.oa?id=350562513001 \\ DOI: https://doi.org/10.24215/18539912e088
}




\title{
As influências das garantias de ficção, literária e de uso na indexação da literatura infantojuvenil: proposta de modelo de leitura ${ }^{1}$
}

\begin{abstract}
Influences of fictional, literary and use warrants in indexation of literature for children and adolescents: proposal of reading model
\end{abstract}

Roberta Caroline Vesu Alves

Universidade Estadual Paulista. Programa de Pós

Graduação em Ciência da Informação, Brasil

DOI: https://doi.org/10.24215/18539912ee88

Redalyc: http://www.redalyc.org/articulo.oa?

robertavesu@gmail.com

$\mathrm{id}=350562513001$

Recepción: 16 Septiembre 2019

Aprobación: 30 Noviembre 2019

\section{Resumo:}

As garantias de ficção, literária e de uso foram verificadas com objetivo de observar se fundamentam a elaboração de modelo de leitura documental para indexação de texto narrativo ficcional em prosa, nos aspectos de identificação de assuntos, seleção e representação. A metodologia consistiu em pesquisa bibliográfica e estudo exploratório para o desenvolvimento do modelo de leitura documental, este avaliado por bibliotecários escolares, também por meio da metodologia do protocolo verbal individual para verificação e aprimoramento do modelo. Como resultados, as garantias de ficção, literária e de uso contribuíram com a fundamentação do modelo de leitura documental para a indexação da literatura infantojuvenil conforme observado na avaliação do modelo. Alguns aspectos da estrutura do modelo foram aprimorados. Os elementos do texto importantes para representação e recuperação da informação por usuários estão relacionados com as garantias e foram evidenciados pelos aspectos de personagens, ação ou evento, espaço, tempo, tema ou assunto, narrador, gêneros literários, temas educacionais do ponto de vista do autor e alguns aspectos cognitivos do leitor. O modelo empírico de leitura documental foi fundamentado pelas garantias e foi importante para indexação por bibliotecários escolares, que aprovaram o modelo e mostraram modos para seu aprimoramento.

PalaVRas-CHAVE: Garantia de ficção, Garantia literária, Garantia de uso, Modelo de Leitura Documental, Indexação, Literatura infantojuvenil.

\section{Abstract:}

The fiction, literary, and user warranties were verified in order to observe if they base the elaboration of a documentary reading model for indexing fictional narrative text in prose, in the aspects of subject identification, selection and representation. The methodology consisted of bibliographic research and exploratory study, with qualitative analysis for the development of documentary reading model, which was evaluated by school librarians through the methodology of individual verbal protocol to verify and improve the model. As results, warranties of fiction, literary and use contribute to foundation of documentary reading model for indexation of literature for children and adolescents as observed in the model evaluation. Some aspects of model had to be improved. Important text elements for representation and retrieval of information by users are related to warranties and were evidenced by characters, action or event, space, time, theme or subject, narrator, literary genres, educational themes from author's point of view and some cognitive aspects of reader. The empirical model of documentary reading was based on warranties and was important for indexing by school librarians, who approved of applying the model and showed ways to improve.

KEYWORDS: Fictional warrant, Literary warrant, User warrant, Document Reading Model, Indexing, Literature for children and adolescents.

\section{INTRODUÇÃO}

As garantias de ficção, literária e de uso orientam a adequação dos elementos representativos do texto e alertam para a representação de necessidades de informação dos usuários. Também, evidenciam o compromisso que o indexador deve ter ao lidar com procedimentos de indexação desde o início. Um estudo de elaboração de resumos da literatura infantojuvenil, por exemplo, demonstrou que essas garantias tem o potencial de direcionar a representação de modo mais adequado ao considerar as características e 
temáticas textuais, como também as necessidades de informação dos usuários (Alves, 2016). Os elementos característicos do texto ficcional são exigidos como parâmetro de representação pela garantia de ficção, literária e de uso. Esses elementos são caracterizados por: personagem, ação/evento/enredo, espaço, tempo da história, tempo da narrativa, tema ou assunto principal, tipo de narrador, gênero literário e subgênero literário. Outros elementos são as características de aspectos psicológicos e educacionais de crianças e adolescentes.

Os modelos de leitura documentária ou documental são utilizados em indexação com a finalidade de auxiliar os procedimentos de análise para identificação e seleção de conceitos, também para fins de representação e recuperação sobre o conteúdo informacional. Os elementos éticos denominados de garantia de ficção (fictional warrant), garantia literária (literary warrant) e garantia de uso ou do usuário (user warrant) apresentaram o potencial de respeitar a indexação e a representação da literatura infantojuvenil. Contudo, surgiu o problema de pesquisa: quais as influências das garantias de ficção, literária e de uso para a indexação da literatura infantojuvenil? O objetivo da pesquisa consistiu em analisar as influências das garantias de ficção, literária e de uso na literatura infantojuvenil contributivas à fundamentação e elaboração da proposta de modelo de leitura para identificação, seleção e representação de assuntos. O modelo de leitura proposto foi, na sequência dessa investigação, avaliado por bibliotecários escolares durante a prática de indexação da literatura infantojuvenil. Este estudo foi importante para estabelecer o modelo de leitura de modo empírico, para a indexação da literatura infantojuvenil de ficção em prosa, com base nessas garantias.

\section{As garantias DE FICÇÃO, LITERÁRIA E DE USO NA INDEXAÇÃO DA LITERATURA INFANTOJUVENIL}

As garantias são estudadas e apresentadas por Barité (2007, 2009, 2018), Barité et al. (2010), Beghtol (1986, 1989, 1994, 1995), Hjørland (2013), Laipelt (2015), National Information Standards Organization (2010), Oliveira e Araújo (2012) e Van Der Walt (2004), entre outros, nas áreas de Organização do conhecimento e ciência da informação, pois são áreas com grande interlocução teórica. Apesar disso, essas garantias apresentam pouca discussão teórica para orientar os modos de representação. A garantia de ficção (fictional warrant), a garantia literária (literary warrant) e a garantia de uso (user warrant) são princípios éticos que fundamentam a representação por sistemas de classificação bibliográfica e vocabulários controlados. Mas, são consideradas nesta pesquisa desde o processo de indexação de assuntos, que permite a elaboração e atualização da linguagem de indexação e vocabulários controlados.

A garantia literária garante que os assuntos dos textos sejam representados de modo preciso, a de ficção, valida as características do texto ficcional para representação, e a terceira, que a representação corresponda ao que é importante para recuperação dos usuários (Beghtol, 1994; Barité et al., 2010). Barité (2018) afirma que a ideia garantia literária foi desenvolvida inicialmente pelo pesquisador Hulme (1859-1954), que estabeleceu nos princípios de classificação que uma classe tem garantia quando se assemelha a uma obra ou documento de modo preciso. Mas, o pesquisador não desenvolveu mais do que essa noção básica (Barité, 2018). Na norma ANSI/NISO Z-39.19 da National Information Standards Organization $\left(2010\right.$, p. 6) ${ }^{2}$, a garantia literária é definida como a "justificativa para a representação de um conceito em uma linguagem de indexação ou para a seleção de um termo preferido por causa de sua ocorrência frequente na literatura”.

De acordo com Beghtol (1994) e Barité et al. (2010), a garantia literária é um conceito desenvolvido no contexto de sistemas de classificação bibliográfica, mas foi ampliado para representações em indexação. A garantia literária estabelece que a documentação "[...] atua como fonte de validação dos termos a serem incluídos em um sistema de organização do conhecimento, pois o que se classifica e se indexa são temas presentes nos documentos”, por isso, as representações são passíveis de adaptarem-se à dinâmica da documentação (Barité et al., 2010, p. 125). Na concepção de Barité (2018), a garantia literária se apresenta como método de justificação da terminologia compilada do documento, ainda é inerente ao estágio anterior 
da padronização dos termos em vocabulário controlado. A garantia literária e o controle do vocabulário, segundo o mesmo autor, são complementares, pois "a garantia literária fornece os termos de referência e o controle de vocabulário fornece sua configuração definitiva e as relações entre os termos” (Barité, 2018, p. $521) .^{3}$

O conceito de garantia literária foi expandido para princípio de procedimentos e de representação, também para política de padronização de procedimentos de classificação e de estabelecimento de termos de indexação, entre outros aspectos, segundo Barité (2018). Além disso, a garantia do usuário demonstra que o vocabulário controlado deve ser elaborado conforme as solicitações dos usuários, o que complementa o potencial de uso de sinônimos, por exemplo, bem como a escolha de termos preferidos e não preferidos (Barité, 2018).

De acordo com Van der Walt (2004), as garantias respeitam o documento e apresentam uma representação confiável, além disso, respeitam as necessidades de informação dos usuários. Ainda, o autor manifesta que esses aspectos estão relacionados com reponsabilidade social dos indexadores e classificadores, diante de comunidades amplas e específicas. Nesse sentido, a garantia literária evoluiu, de acordo com Barité (2009), e a representação não está respaldada somente na literatura, mas também na opinião dos usuários, além de se apresentar culturalmente determinada. Apesar do exposto, o mais comum é que "[...] a garantia literária encontra-se estreitamente vinculada aos aspectos semânticos das formas de representação próprias à classificação e à indexação (descritores, cabeçalhos de assunto, notações classificatórias)" (Barité et al., 2010, p. 126). A garantia literária está relacionada com aspectos semânticos e terminológicos de linguagens de indexação, que de certa forma são provenientes do processo de indexação (Alves, 2016). Também, relacionada com a garantia de ficção, pois estabelece e demonstra as características dos textos ficcionais para representação.

A garantia de ficção, de acordo com Beghtol (1994), decorre das características dos textos narrativos de ficção em prosa. Esse princípio garante que as características dos documentos ou textos de ficção sejam representadas na classificação, ou seja, que ocorra a representação dos quatro elementos básicos da ficção, segundo Beghtol (1994, p. 158): “[...] personagem, evento, espaço e tempo”. ${ }^{4}$ Contudo, esses elementos textuais também são usados para indexação, por isso, a garantia de ficção também vale para representação e procedimentos de indexação de assuntos. Nesse contexto, a garantia do usuário é aumentada com a garantia de ficção, pois, os conhecimentos dos usuários sobre textos ficcionais podem coincidir com as características do texto (Beghtol, 1994). A garantia de uso ou do usuário é definida como,

Justificativa para a representação de um conceito em uma linguagem de indexação ou para a seleção de um termo preferencial devido a pedidos frequentes de informações sobre o conceito ou pesquisas de texto livre sobre o termo pelos usuários de um sistema de armazenamento e recuperação de informações. (National Information Standards Organization, 2010, p. 10, tradução nossa).

A garantia do usuário, ou garantia de uso, mostra a importância das solicitações e das formas de buscas dos usuários para compor as representações (Barité et al., 2010). Entende-se que a representação deve estar mais próxima do contexto de comunicação dos usuários com o sistema de informação (Alves, 2016). Assim, é necessário prover aos usuários a informação mais atual e precisa, também, é de grande valor que o processo de indexação contemple as diversas variantes que o vocabulário do usuário apresente. Oliveira e Araujo (2012, pp. 23-24), afirmam que a temática a garantia do usuário está relacionada com a construção das “[...] linguagens de indexação que se apresentam como instrumentos indispensáveis à recuperação da informação". Hjørland (2013) questiona se a garantia do usuário consiste em uma alternativa ou um complemento para a garantia literária. A discussão de criar sistemas de bibliotecas, base de dados e congêneres, segundo a demanda do usuário ou segundo princípios e critérios acadêmicos de qualidade são importantes. Entretanto, o autor observa, entre outros aspectos, que as necessidades dos usuários ainda são importantes para a elaboração de sistemas e recuperação da informação. Segundo Laipelt (2015, p. 151): 
O resultado da pouca interação entre usuários e bibliotecários é uma das principais causas das dificuldades dos usuários para a recuperação da informação. Visto que, muitas vezes, os descritores atribuídos por bibliotecários aos documentos, durante o processo de representação do conteúdo dos mesmos (indexação), são diferentes dos termos utilizados pelos usuários durante o processo de busca de informação. Isso dificulta, e pode até impossibilitar a recuperação de documentos pertinentes aos interesses/necessidades dos usuários.

Por isso, a consciência do bibliotecário sobre a necessidade de informação dos usuários é muito importante, ou seja, observar diretamente as necessidades de busca ou, segundo Laipelt (2015), realizar a análise de logs de buscas dos usuários. Estes consistem no "[...] registro da interação dos usuários com o sistema de recuperação da informação" (Laipelt, 2015, p. 159). Assim, pode ser verificada a linguagem do usuário no sistema de recuperação da informação, o que contribuirá com a adequação da linguagem de indexação.

Vale destacar que algumas pesquisas mostram solicitações dos usuários de bibliotecas escolares sobre literatura infantojuvenil, que são importantes para serem consideradas na recuperação da informação, portanto, importantes de serem representadas em indexação e resumos. Algumas dessas necessidades de informação são provenientes de elementos temáticos como: aventura, amor, amizade, guerra, bruxo, princesa, superação, preconceito, entre outras para diversão, bem como elementos para a aprendizagem do texto narrativo, conforme o tipo de narrador, espaço, tempo etc. (Alves, 2008, 2016). Isso demonstra a importância do estudo sobre indexação da literatura infantojuvenil, para atender necessidades de informação dos usuários.

Outro fator importante, nesse contexto, é a busca e indicação de leitura pelo professor ao aluno, de acordo com a fase de desenvolvimento cognitivo ou psicológico da criança e do adolescente em relação à leitura, o que configura uma necessidade de informação pelo usuário a ser assegurada pela garantia de uso. Nesse sentido, as categorias do leitor, segundo Coelho (2010) e Gregorin Filho (2009) mostram os tipos de leitor em cada fase do ensino escolar, que foram consideradas no modelo de leitura documental. Outros temas importantes no âmbito escolar são os “Temas Transversais dos Parâmetros Curriculares Nacionais” (BRASIL, 1997, 1998), buscados nas bibliotecas escolares para desenvolver o ensino sobre a cidadania.

A literatura infantojuvenil abre caminhos para crianças e adolescentes conhecerem os textos escritos, que materializaram discursos com a cultura de determinado povo ou sociedade. Para esse conhecimento, a criança começa a entender, de modo gradual, as formas e conteúdos da narrativa e da poética, entre outros aspectos do discurso literário, ao aprender e desenvolver suas habilidades de leitura. A função da literatura infantojuvenil, segundo Colomer (2017), já apresentou uma visão educativa e de aprendizagem de comportamento muito forte. Atualmente, no entanto, está mais voltada para agradar o leitor e levá-lo ao descobrimento de diferentes linguagens. A autora afirma que apresenta três principais funções:

1. Iniciar o acesso ao imaginário compartilhado por uma determinada sociedade.

2. Desenvolver o domínio da linguagem através das formas narrativas, poéticas e dramáticas do discurso literário.

3. Oferecer uma representação articulada do mundo que sirva como instrumento de socialização das novas gerações.

Conforme, Gregorin Filho (2009), a literatura infantil é um objeto de arte, onde o texto organiza as ideias do discurso sobre algum aspecto do mundo e sua ideologia. Também, contribui para transmitir a identidade cultural de um povo. Ainda, "[...] utilizar-se da literatura como veículo de informação e lazer promove a formação de um indivíduo mais capaz de argumentar, de interagir com o mundo que o rodeia e tornarse agente de modificações na sociedade em que vive." (Gregorin Filho, 2009, p. 51). Os tipos de literatura infantojuvenil que levam ao lazer e educação são inúmeros. Apesar de não se pretender esgotar os tipos de literatura infantojuvenil, pois as categorizações a respeito dessa literatura são diversas, pode-se entender que alguns tipos dessa literatura são: biografias, comédias, contos, crônicas, epopeias, ficção didática, ficção histórica, folclore, histórias de amor, histórias de aventuras, histórias infantis diversas etc. (Barbosa, Mey e 
Silveira, 2005). Esses, entre e outros tipos de texto, são importantes para retratar o mundo e as pessoas, e são veículos importantes para desenvolvimento intelectual, social e emocional de crianças e adolescentes.

Os textos literários, independente de seu tipo ou gênero, usam alguns elementos para sua composição, que para esta pesquisa são explicados por: teoria da narrativa (D’Onofrio, 2007, Gancho, 2014, Terra, 2014); alguns aspectos da linguística textual (Van Dijk, 2000, 2004), como a coesão, coerência, superestrutura (tipo de texto em que o conteúdo se adapta), macroestrutura (semântica global e parcial do texto) e microestruturas (palavras organizadas); elementos da enunciação e de produção de sentido, por exemplo, o percurso gerativo de sentido, que, em especial, no nível narrativo estabelece a existência da relação de manipulação (ação) entre o manipulador e o manipulado (Fiorin, 1999, 2014, 2015). Esses elementos são capazes de explicar as composições básicas de qualquer tipo de texto e sua produção de sentido.

De acordo com Gregorin Filho (2011), os tipos de literatura voltados para crianças e adolescentes se alteraram bastante ao longo do tempo. Porém, permeiam nesses textos, aspectos ideológicos de visão de mundo, educativos e valores esperados por uma sociedade para os indivíduos mais novos. Em especial, na literatura juvenil, é muito importante, atualmente, mostrar experiências humanas ao leitor por meio da ficção, tais como: realidades existenciais, sociais e culturais, de acordo com linguagem adequada ao seu público.

Diante do exposto, verifica-se que é muito importante entender o sentido da literatura infantojuvenil para identificar e selecionar os assuntos para fins de representação e recuperação da informação conforme as garantias de ficção, literária e de uso. Essas garantias têm o potencial de contribuir para o processo de indexação na fundamentação do modelo de leitura documental, pois a representação é decorrente dos processos anteriores de identificação e seleção de assuntos.

\section{Procedimentos de indexaÇão E MOdelo de leitura documental: ANÁlise DE ASSUNTO PARA IDENTIFICAÇÃo, SELEÇÃo DE CONCEITOS E REPRESENTAÇÃo DE INFORMAÇÕES}

A indexação, como procedimento da Análise Documental, desenvolve principalmente os processos de leitura, análise, síntese e representação do conteúdo dos documentos para fins de recuperação da informação. Gardin (1981, p. 29 apud Silva e Fujita, 2004, p. 136) conceitua a análise documental como "um conjunto de procedimentos efetuados com a finalidade de expressar o conteúdo de documentos científicos, sob formas destinadas a facilitar a recuperação da informação". Esses procedimentos são inerentes à indexação, que “[...] surgiu a partir da elaboração de índices e atualmente está mais vinculada ao conceito de análise de assunto" (Silva e Fujita, 2004, p. 136).

Nesse sentido, as etapas do processo de indexação, conforme indicadas por Fujita (2013) são: a) análise de assunto, que identifica e seleciona os principais tópicos do assunto do documento; e b) tradução desses tópicos por meio de linguagem de indexação. Essas etapas são importantes, pois esclarecem os procedimentos de análise, seleção e tradução para representação. Especificamente, a análise de assuntos conta com procedimentos de leitura documental apoiada por modelo de leitura. Para Silva e Fujita (2004, p. 147):

A leitura documentária faz-se presente no momento em que o indexador realiza a análise do assunto tratado em um documento a fim de representá-lo em termos de indexação. É nesse momento que se inicia a identificação de conceitos principal etapa da análise de assunto - por meio da qual o indexador compreende os conceitos tratados em um documento, bem como verifica sua importância para seu sistema de informação.

A realização da leitura documental se dá por meio de ações cognitivas conscientes e inconscientes, que identificam a estrutura textual e as partes importantes do texto, bem como seus conceitos (Fujita, 2003). Os modelos de leitura documental apresentam, principalmente, estratégias de identificação da estrutura textual e de inferência devido aos questionamentos ao texto. O objetivo do modelo de leitura documental é a identificação e seleção de assuntos para fins de representação de termos em linguagem de indexação. Para 
isso, a leitura documental tem que ser realizada de modo profissional (direcionada e rápida) e padronizar o trabalho do indexador, que passa a direcionar a leitura de modo consciente, segundo as estratégias metacognitivas que norteiam o seu entendimento para aspectos da estrutura textual e elementos temáticos importantes.

O modelo de leitura documental de Fujita e Rubi (2006) apoiado na identificação da superestrutura textual e questionamento ao texto apresenta procedimentos de: "Exploração do conhecimento da estrutura textual; Identificação de conceitos; Seleção de conceitos". Inicialmente elaborado para indexação de textos científicos, posteriormente, esse modelo serviu de base aos outros modelos de leitura desenvolvidos para diferentes estruturas textuais (Fujita, 2013, Sabbag, 2017). E outros que serviram de parâmetro metodológico para a proposta de modelo de leitura desta pesquisa como alguns aspectos dos modelos de Alves (2017) e de Fujita et al. (2017).

Além disso, segundo Fujita e Rubi (2006), a identificação do tema pode ser feita por inferência ao texto ao utilizar questionamentos por categorias temáticas: "o que? (Categoria essencial); quando? onde? como? (Categorias acessórias), que podemos denominar de estratégia de inferência e considerá-la como elemento fundamental dos modelos de leitura para indexação", além da estrutura textual. A estratégia de inferência é também orientada pela Norma 12.676 (Associação Brasileira de Normas Técnicas, 1992), mediante questionamento que direciona a identificação de conceitos, e no sistema PRECIS (PReserved Context Indexing System), que apresenta conceitos universais: "O que aconteceu? (ação); A que ou a quem isto aconteceu? (Objeto da ação - sistema chave); O que ou quem fez isto? (Agente da ação); Onde aconteceu? (Local)", entre outros fatores. Por isso, esses e outros aspectos, especialmente os apontados por Alves (2017), Fujita et al. (2017), foram analisados para a elaboração do modelo de leitura documental na indexação da literatura infantojuvenil, que foi avaliado posteriormente por bibliotecários, sujeitos da pesquisa.

\section{Metodologia}

A metodologia desta pesquisa foi desenvolvida em duas etapas: (1) a elaboração da proposta de modelo de leitura documental para indexação da literatura infantojuvenil; (2) e avaliação para adequação e aprimoramento do modelo elaborado. Na primeira etapa foram usados os métodos de Pesquisa Bibliográfica e de Estudo Exploratório para embasamento teórico, pois de modo interdisciplinar foi necessário analisar elementos teóricos diversos da indexação e relacioná-los com as garantias a fim de contribuírem com o modelo de leitura específico. Para a elaboração do modelo empírico de leitura foram considerados: procedimentos para elaboração de um modelo de leitura documental, segundo Fujita e Rubi (2006), conforme o "uso combinado da exploração da estrutura textual com o questionamento para a identificação de conceitos"; elementos da estrutura textual de texto narrativo ficcional em prosa explicados por teorias da narrativa, percurso gerativo de sentido e linguística textual; questionamentos adequados para esse texto; e a relação inerente com as garantias literária, de ficção e do usuário.

Após elaboração do modelo empírico de leitura documental para textos infantojuvenis, conforme as exigências principais para esse modelo, procedeu-se à fase de sua avaliação e adequação com a metodologia ou técnica introspectiva de Protocolo Verbal Individual, que foi utilizada para coleta de dados. Isso, na tarefa de indexação por bibliotecários escolares com o uso do modelo de leitura proposto, a fim deste ser avaliado e adequado diante das observações dos sujeitos pesquisados. O protocolo verbal, segundo Boccato, Fujita e Rubi (2010, p. 109), "[...] consiste na gravação da exteriorização verbal do pensamento de um ou mais indivíduos durante a realização de uma tarefa. O 'pensar alto' do sujeito é gravado e transcrito literalmente”. A coleta de dados com a técnica introspectiva de protocolo verbal individual (Fujita, 1999, Fujita, Nardi e Fagundes, 2003) é formada de três etapas: 1- Procedimentos anteriores à aplicação do protocolo verbal individual (Seleção dos sujeitos: dois bibliotecários escolares de escolas do estado de São Paulo, Brasil, que selecionaram por livre escolha dois livros de literatura infatojuvenil de ficção em prosa para indexação, 
voltados para diferentes idades de leitores; Conversa informal com os sujeitos para mencionar os objetivos da pesquisa e garantir que as suas identidades e as das suas instituições não serão divulgadas; No dia da coleta de dados foi esclarecido o Modelo Empírico de Leitura Documental; e realizada a familiarização da tarefa de "pensar alto" e protocolo verbal individual); 2- Procedimentos durante a aplicação do protocolo verbal individual (Gravação do "pensar alto" durantea indexação, além disso, o pesquisador lembrou aos sujeitos a sempre "pensar alto", também a ler novamente o modelo, quando necessário); 3- Procedimentos após a aplicação do protocolo verbal individual (Entrevista retrospectiva para sanar dúvidas e avaliar o modelo; Transcrições literais das gravações feitas pela pesquisadora sobre as falas, com notações, e análise sobre a utilidade do modelo de leitura documental e as sugestões de adequações).

Desse modo, após esses procedimentos foi proposta a elaboração da adequação do modelo de leitura documental, de caráter empírico. Pois, a elaboração desse modelo estava aberta para a avaliação e contribuição de profissionais experientes para seu aprimoramento, conforme o entendimento e realidade dos sujeitos pesquisados e de seus usuários.

\section{Proposta EMpírica de MODElo DE LEITURA DOCUMENTAL PARA INDEXAÇÃo DA LITERATURA INFANTOJUVENIL DE FICÇÃO EM PROSA PARA BIBLIOTECA ESCOLAR}

A proposta de modelo de leitura documental visou contribuir com a indexação da literatura infantojuvenil de texto narrativo em prosa no contexto da biblioteca escolar, principalmente, nos aspectos de leitura para identificação de assuntos e seleção de assuntos ou temas. Depois, esses assuntos podem ser representados a critério do bibliotecário, conforme necessidades dos usuários e das regras da instituição.

O modelo de leitura documental proposto apresentou aspectos sobre as estruturas textuais e as temáticas explicadas por autores como Alves (2017), Beghtol (1994), D’Onofrio (2007), Fiorin (1999, 2014, 2015) que se baseou em A. J. Greimas (1917-1992), Fujita (2009, 2013), Fujita et al. (2017), Fujita e Rubi (2006), Gancho (2014), Personagem (2017), Sabbag (2017), Terra (2014), e Van Dijk (2000, 2004). Também, apresentou metodologia de identificação de conteúdo, combinando as estratégias de conhecimento de estruturas textuais para compor estratégias metacognitivas de reconhecimento de partes texto e estratégias de inferência (questionamento ao texto), principalmente, com base em Fujita e Rubi (2006).

Além de considerar as garantias de ficção e literária para identificação de conteúdo e a garantia de uso para a seleção e representação conforme as necessidades dos usuários. Mas, nem todos os elementos teóricos foram utilizados inicialmente, exceto o das garantias, pois foram adaptados posteriormente com as avaliações dos sujeitos pesquisados. A identificação precisa e seleção dos assuntos e sua representação de acordo com os termos do texto, traduzidos aos da linguagem de indexação, respeitou a garantia literária, a de ficção e a do usuário. Além disso, no âmbito do texto ficcional as garantias são válidas também para termos abstraídos e relacionados ao texto, o que complementa a representação com temas pertinentes e advindos da conotação e metáforas inerentes ao texto literário, entre outros aspectos. A seleção de assuntos relacionados com o sentido abstrato também foi de encontro com as necessidades de informação dos usuários e respeitou a garantia do usuário. A seguir, estão os principais elementos dos modelos de leitura analisados para sua elaboração, conforme categorias e questionamentos.

Os questionamentos por categorias básicas de Fujita e Rubi (2006) são: O que? (categoria essencial); categorias acessórias: Quando?; Onde?; Como?. Também, os questionamentos do modelo para indexação de textos científicos (Fujita e Rubi, 2006) são:

1. $\mathrm{O}$ assunto contém uma ação (podendo significar uma operação, um processo etc.)?; 2. $\mathrm{O}$ documento possui em seu contexto um objeto sob efeito desta ação?; 2 .1 O objeto identificado pode ser considerado como parte de uma totalidade?; 2.2 O objeto identificado possui características ou atributos particulares?; 3 . O documento possui um agente que praticou esta ação?; 4. Para estudo do objeto ou implementação da ação, o documento cita e/ou descreve modos específicos, por exemplo: 
instrumentos especiais, técnicas, métodos, materiais e equipamentos?; 5 . a ação, objeto e agente são considerados no contexto de um lugar específico ou ambiente?; 6. Considerando que a ação e o objeto identificam uma causa, qual é o efeito desta causa?

As categorias e questionamentos do MENTIF, Fujita et al. (2017, p. 14-15) são:

Personagem - Existem seres ou atores que existem e participam no mundo da ficção (inclui o narrador quando for o caso)? Observação: Seres (animados, inanimados, imaginários: pessoa, animal, pedra, fantasma, etc.). Características dos seres que merecem destaque (classe, gênero, profissão, personalidade, nacionalidade; quando ligado a evento histórico identificar nome pessoal); Evento - Existem ocorrências e acontecimentos do mundo real e não real (inclui atos humanos e não humanos)? Observações: Ocorrências e acontecimentos fatos, ações, fenômenos naturais, sobrenaturais, situações, cerimônias, relacionamentos, sentimentos, etc.); Espaço - A narração acontece em um determinado lugar geográfico ou localização (ou ambiente) no mundo ficcional?; Tempo - Existe uma unidade de tempo no mundo ficcional? Observação: Unidade de tempo (período de tempo específico).

As partes do texto / questionamentos do modelo de leitura de fábulas infantis (Alves, 2017, p. 149) são:

GÊNERO DISCURSIVO / Qual o gênero e subgênero discursivo?; ENREDO - APRESENTAÇÃO: PERSONAGENS / Quem são os personagens principais? Quais as características importantes dos personagens principais?; ENREDO APRESENTAÇÃO: ESPAÇO / Em que cenário ocorrea ação ou enredo? Em que ambiente ocorre a ação ou enredo?; ENREDO - APRESENTAÇÃO: TEMPO / Em que época se passa a história? Quanto tempo dura a história? O tempo é apresentado de modo cronológico ou psicológico?; ENREDO - COMPLICAÇÃO / Qual o conflito apresentado?/ ENREDO - CLÍMAX / Qual o clímax ou ponto máximo do conflito?; ENREDO - DESFECHO / Qual o desfecho do conflito?; MORAL DA HISTÓRIA (NO FINAL DO TEXTO) / Qual a moral da história?; NARRADOR / Qual o tipo de narrador?

Diante disso, entende-se que os principais elementos de inferência ao tema para os textos ficcionais infantojuvenis, que validam as garantias de ficção e literária compreendem os questionamentos por categorias básicas como: "O que? (categoria essencial)" e "O que aconteceu? (ação)" em relação ao evento e enredo; "A que ou a quem isto aconteceu?" e "O que ou quem fez isto? (agente da ação)" em relação aos personagens principais e narrador personagem; “Quando?” em relação ao tempo; “Onde?” e "Onde aconteceu? (local)” em relação ao espaço; a relação de causa e efeito pode ser compreendida no texto ficcional, principalmente em relação ao efeito pelo "Enredo - Desfecho / qual o desfecho do conflito?" e "Moral da história (no final do texto) / qual a moral da história?”. Nesse contexto, o personagem principal pode ser ou não o objeto da ação, porque o personagem manipulador pode exercer manipulação ao personagem manipulado (ação do manipulador/personagem + objeto manipulado/personagem = personagem manipulado ou sujeito passivo da ação de manipulação), ou o manipulado/personagem pode ser o próprio protagonista da ação (personagem + ação = agente da ação).

A relação do efeito com o enredo-desfecho e moral da história existe, a partir do potencial de que uma ação é motivada por algo, uma causa, e que tem um efeito final (desfecho). A causa de uma ação em um texto ficcional pode ocorrer por inúmeros motivos, entre eles na situação de manipulação, que leva um sujeito a fazer, transformar seu ser e fazer algo, descobrir, levar o sujeito manipulado a sentir algo etc.

As garantias fundamentam a proposta de modelo empírico de leitura documental e outros aspectos da proposta conforme constam no quadro 1 . 
Quadro 1 - Modelo Empírico de Leitura Documental da literatura infantojuvenil para de exploração da estrutura textual e identificação de assuntos e temas por meio de questionamentos ao texto - primeira proposta.

\begin{tabular}{|c|c|c|c|}
\hline $\begin{array}{c}\text { PARTES DA } \\
\text { ESTRUTURA DO } \\
\text { TEXTO } \\
\end{array}$ & $\begin{array}{l}\text { CONCEITOS DA } \\
\text { ESTRUTURA TEXTUAL }\end{array}$ & $\begin{array}{l}\text { QUESTIONAMENTOS PARA IDENTIFICAÇÄO DOS } \\
\text { TEMAS OU ASSUNTOS DO TEXTO }\end{array}$ & $\begin{array}{l}\text { IDENTIFICA-ÇAO } \\
\text { DE TEMAS OU } \\
\text { ASSUNTOS }\end{array}$ \\
\hline \multirow{2}{*}{$\begin{array}{l}\text { Elementos } \\
\text { preliminares do } \\
\text { texto } \\
\text { (Informações da } \\
\text { capa, folha de rosto, } \\
\text { última capa e orelhas } \\
\text { do livro, } \\
\text { Apresentação ou } \\
\text { algum elemento pré- } \\
\text { textual, Folheto } \\
\text { explicativo e } \\
\text { Sumário) }\end{array}$} & $\begin{array}{l}\text { Tema ou assunto - } 0 \\
\text { quê? (tema e categoria } \\
\text { essencial) }\end{array}$ & $\begin{array}{l}\text { 1) Qual o tema ou assunto apontado nos elementos } \\
\text { preliminares da obra? } \\
\text { Observação: para ser comparado e analisado com os } \\
\text { elementos textuais. }\end{array}$ & \\
\hline & $\begin{array}{l}\text { Gênero textuale } \\
\text { Subgêneros textuais }\end{array}$ & 2) Qual o gênero textuale os subgêneros textuais? & \\
\hline \multirow{6}{*}{$\begin{array}{l}\text { Capitulos iniciais } \\
\text { (2. primeiros capitulos } \\
\text { ou folhas iniciais) }\end{array}$} & $\begin{array}{l}\text { Gênero textual } e \\
\text { Subgêneros textuais }\end{array}$ & $\begin{array}{l}\text { 3) Qual o gênero textual e os subgêneros textuais? } \\
\text { Observação: utilizar se não foi possível identificar } \\
\text { anteriormente. }\end{array}$ & \\
\hline & $\begin{array}{l}\text { Ação/evento/ enredo - O } \\
\text { quê? (tema e categoria } \\
\text { essencial) }\end{array}$ & $\begin{array}{l}\text { 4) Qual a ação ou acontecimento que leva ao } \\
\text { desenvolvimento de toda narrativa? } \\
\text { Observação: algo que instigou o personagem principal a } \\
\text { fazer de importante (relacionado com a manipulação). }\end{array}$ & \\
\hline & Ação/evento/ enredo & 5) Quais demais ações e acontecimentos relevantes? & \\
\hline & $\begin{array}{l}\text { Personagem principal } \\
\text { (geralmente o } \\
\text { personagem do mal ou } \\
\text { viläo) }\end{array}$ & $\begin{array}{l}\text { 6) Quem é o personagem manipulador? } \\
\text { Observação: personagem principal (herói ou vilão). } \\
\text { Características de: nomes; características físicas; } \\
\text { características psicológicas (boas e más). }\end{array}$ & \\
\hline & $\begin{array}{l}\text { Personagem principal } \\
\text { (geralmente o } \\
\text { personagem do bemou } \\
\text { herói) }\end{array}$ & $\begin{array}{l}\text { 7) Quem é o personagem manipulado? } \\
\text { Observação: personagem principal (herói ou vilão). } \\
\text { Características de: nomes; características físicas; } \\
\text { características psicológicas (boas e más). }\end{array}$ & \\
\hline & Narrador & $\begin{array}{l}\text { 8) Qual o tipo de narrador? } \\
\text { Observação: verbos em primeira pessoa (narrador } \\
\text { personagem e narradortestemunha, que vive a história, } \\
\text { mas não é o personagem principal); verbos em terceira } \\
\text { pessoa (narrador observador que mostra os fatos à medida } \\
\text { que acontecem, e narrador onisciente que sabe tudo, } \\
\text { incluindo como os personagens se sentem). }\end{array}$ & \\
\hline
\end{tabular}




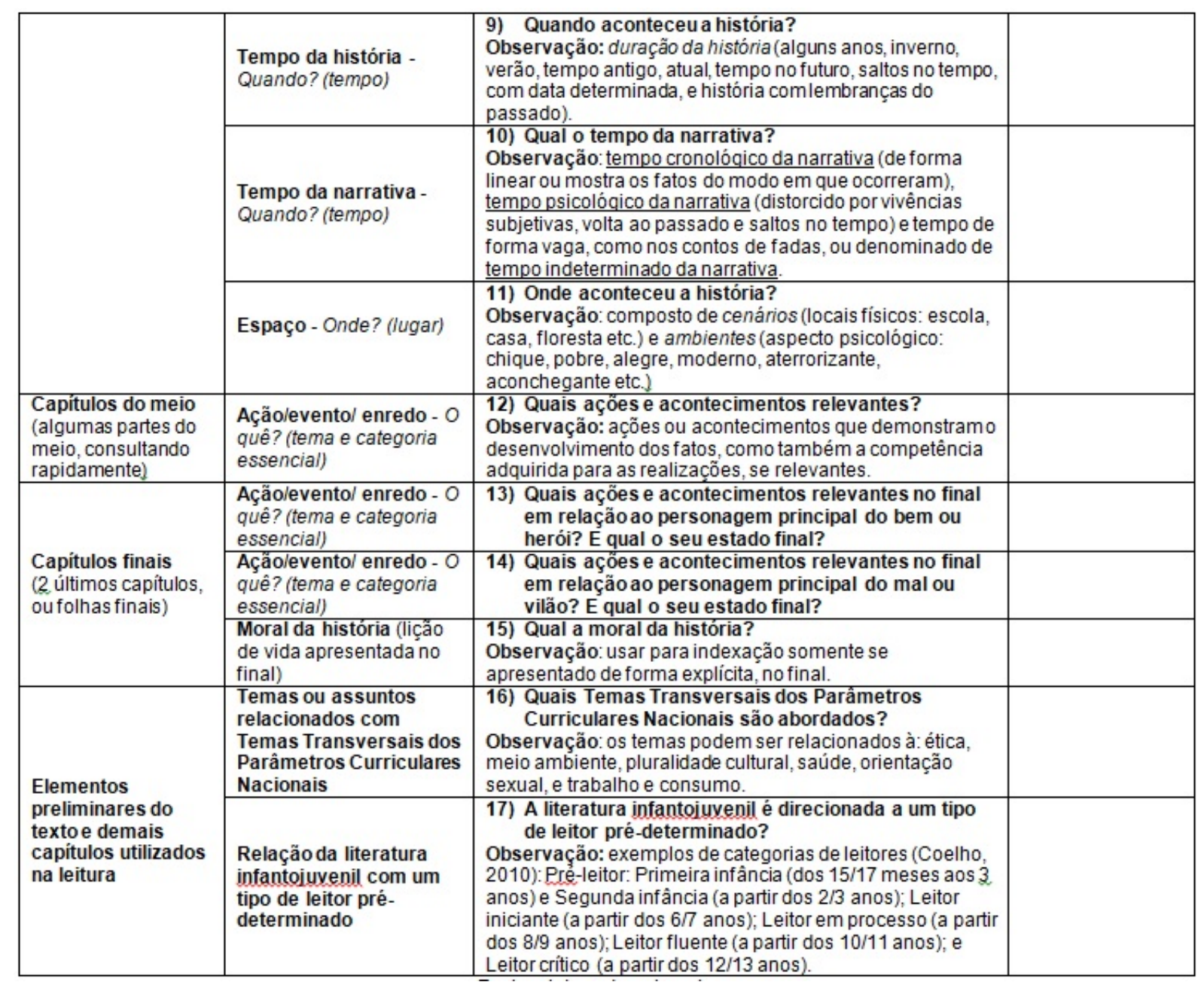

Fonte: elaborado pela autora.

O quadro 1 serve de apoio para o entendimento de instruções mais detalhadas do Modelo Empírico de Leitura Documental, que foram apresentadas aos bibliotecários escolares e abrangeram em um primeiro momento: a exploração da estrutura textual, ou superestrutura, na leitura documental; a compreensão da localização das informações que ocorre pela identificação da estrutura textual, na observação das partes da literatura infantojuvenil em prosa (Informações da capa e folha de rosto; Informações da última capa; Informações das orelhas do livro; Apresentação ou algum elemento pré-textual; folheto explicativo do conteúdo; sumário; capítulos iniciais; capítulos do meio: algumas partes; capítulos finais). A segunda etapa consistiu na localização do conteúdo, assunto ou tema referente a cada parte do texto para identificar os seguintes conceitos: personagens principais; espaço; tempo da história; tempo da narrativa; ação/evento/ enredo; tipos de narrador; gêneros e subgêneros textuais; moral da história bem destacada no final; alguns assuntos decorrentes dos temas transversais dos Parâmetros Curriculares Nacionais (Brasil, 1997, 1998); e as categorias do leitor, caso a biblioteca precisasse trabalhar com indicação de leitura conforme prédeterminado leitor, por exemplo, as categorias de Coelho (2010). Esses temas em conjunto com os demais em relação à estrutura textual formam os elementos essenciais a serem identificados na indexação da literatura infantojuvenil.

Para seleção de termos representativos do texto e sua representação deve ser feita uma reflexão diante dos termos identificados. Além disso, a representação em linguagem de indexação, de termos ficcionais deve ocorrer como no exemplo: "Família - ficção". 


\section{AvaliaçÃo do MODELO EMPÍRICO DE LEITURA DOCUMENTAL: RESUlTADOS E DisCUSSÃo}

O Modelo Empírico de Leitura Documental foi apresentado aos bibliotecários, sujeitos pesquisados. A partir disso, foram realizadas as indexações para avaliação do modelo, que ocorreram, por exemplo, conforme as coletas de dados com aplicação de protocolo verbal individual e apresentadas a seguir em uma amostra, conforme quadro 2 .

Quadro 2 - Assuntos identificados e selecionados pelos sujeitos 1 e 2 pesquisados.

\begin{tabular}{|c|c|}
\hline \multicolumn{2}{|c|}{ Referência da literatura infantojuvenil indexada: Devon, M. (2004). O menino do dedo verde. Rio de Janeiro: José Olímpio. } \\
\hline 1 - Poluição & 1 - Poluição \\
\hline 2 - Ecologia & 2 - Ecologia \\
\hline 3-Guerra e paz & 3-Guerra e paz \\
\hline 4 -Miséria & 4 - Miséria \\
\hline 5 - Sistemas educacionais & 5 - Sistemas educacionais \\
\hline 6 - História de fantasia & 6 - História de fantasia \\
\hline 7 - Literatura infantojuvenil & 7 - Literatura infantojuvenil \\
\hline 8 - Transformação dos lugares & $\ldots$ \\
\hline 9 - Tistu (loiro, olhos azuis e feliz) & $\ldots$ \\
\hline 10 - Narrador observador & $\ldots$ \\
\hline 11 - Tempo cronológico & $\ldots$ \\
\hline 12 - Casa luxuosa e grande & $\ldots$ \\
\hline 13 - Fábricas & $\ldots$ \\
\hline 14 - Cidade [...?] & $\ldots$ \\
\hline 15 - Cadeia & $\ldots$ \\
\hline 16 - Favela & $\ldots$ \\
\hline 17 - Tistu cumpriu o papel & $\ldots$ \\
\hline 18 - Mostrou a importância de transformar a sociedade & $\ldots$ \\
\hline 19 - Meio ambiente & 8 -Meio ambiente \\
\hline 20 - Etica & 9 - Etica \\
\hline 21 - Direitos humanos & 10 - Direitos humanos \\
\hline 22 - A partir dos 10 anos & $\ldots$ \\
\hline Termos identificados - Sujeito 2 & Termos selecionados - Sujeito 2 \\
\hline \multicolumn{2}{|c|}{ Referência da literatura infantojuvenil indexada: Neves, A. (2012). Lino. São Paulo: Callis. } \\
\hline 1-Literatura infantojuvenil & 1 - Literatura infantojuvenil \\
\hline 2 - História infantil, Histórias de relacionamentos & 2-Histórias de relacionamentos \\
\hline $\begin{array}{l}3 \text { - Lino, porquinho de brinquedo; Lua, coelhinho que a barriga acende; } \\
\text { Estrela, humana }\end{array}$ & $\cdots$ \\
\hline $4-$ Narrador observador & $\ldots$ \\
\hline 5-Fábrica de brinquedos; casa da Estrela & 3-Fábrica de brinquedos \\
\hline $6-$ Alguns dias & $\ldots$ \\
\hline 7 -Tempo de forma vaga & $\ldots$ \\
\hline 8-A compra de Lino por Estrela; solidåo; amizade; felicidade & 4-Solidåo; amizade; felicidade \\
\hline 9 -Reencontro; felicidade & 5-Reencontro \\
\hline 10- História de amizade & $\ldots$ \\
\hline 11 - Leitor em processo (EF), a partir de 7 anos & 11- Leitor em processo, a partir de 7 anos \\
\hline
\end{tabular}

Fonte: Elaborado pela autora, com base na coleta de dados dos sujeitos 1 e 2 .

As principais contribuições do sujeito 1 para o aprimoramento do modelo de leitura, declaradas na entrevista retrospectiva foram: alertar que o tema principal não está somente nas ações, mas também nos sentimentos dos personagens, pois este carrega o tema principal; os nomes de personagens comuns não foram selecionados por não serem famosos; o termo herói confunde na indexação da literatura infantil; tempos curtos não são relevantes; não são necessários os temas transversais para a maioria dos livros; a maioria das perguntas do modelo não encaixa para alguns livros infantis, por isso declarou ser necessário outro modelo para livros infantis com texto, isso porque conforme apontado por gesto, mas não declarado, e depois verificado, alguns livros infantis apresentam enfoque na descrição da natureza, objetos, comparação de coisas pequenas e grandes (temas com objetivo educacional), que são coisas que os personagens descobrem; importância de incluir característica social do personagem (empresário, papai, filho etc.); os termos precisos remetem a termos abstratos que podem ser indexados; necessidade de modificação das categorias do leitor em relação ao livro adequado de Coelho (2010) para uma mais atual. Portanto, essas categorias do leitor foram atualizadas, segundo Gregorin Filho (2009). 
As contribuições relevantes do sujeito 2 para o aprimoramento do modelo de leitura, conforme verificado na entrevista retrospectiva foram: necessidade de aumentar o vocabulário controlado de Barbosa Mey e Silveira (2005); o modelo de leitura poderia perguntar se existe algum sentimento importante em relação aos personagens (deixar isso de forma clara no modelo); o objeto de valor felicidade é mais importante na primeira história indexada, do que o fazer (ação) que transformou o sentimento em felicidade; seria útil selecionar o nome dos personagens para representação, apesar de no momento não ser usado para recuperação; os locais são importantes para seleção de termos; saber o que acontece no final também é importante; o modelo deve indicar que se não for encontrada a ação e sentimentos principais no começo pode avançar na leitura dos capítulos; necessidade de deixar claro que o texto pode apresentar mais que um tempo e mais que um tipo de narrador; existe muita busca por leitura por idade do leitor; e os temas transversais são importantes e são bastante buscados, por exemplo o bullying.

Os sujeitos pesquisados conseguiram utilizar o modelo de leitura documental, baseado nas garantias de ficção, literária e de uso na indexação, também, usaram as estratégias metacognitivas de identificação da estrutura textual e as estratégias de inferência conforme os questionamentos ao texto. Ainda, concordaram que não é necessário ler o livro todo, mas apenas algumas partes, conforme demarcadas pelo modelo. Além disso, que foi importante realizar a indexação por meio de modelo de leitura documental específico, que de modo geral, contribuiu para a indexação. Especificamente, as opiniões dos sujeitos contribuíram para o aprimoramento do modelo, que teve sua adaptação conforme Apêndices A e B.

\section{CONSIDERAÇÕES FINAIS}

As influências das garantias de ficção, literária e de uso foram importantes para fundamentação de procedimentos de indexação da literatura infantojuvenil de ficção em prosa, principalmente na elaboração da proposta de modelo empírico de leitura documental para identificação de assuntos, seleção e representação. Especificamente, as garantias de ficção e literária respaldaram a precisão necessária para representação dos termos característicos e advindos do texto da literatura infantojuvenil, incluindo os termos abstratos e generalizados (entendidos e não literalmente encontrados no texto). A seleção de termos identificados na literatura infantojuvenil, em especial, mostra a garantia do usuário no cuidado do bibliotecário em escolher os termos representativos do documento e que são importantes para os usuários.

Os elementos característicos do texto ficcional apresentados no modelo de leitura documental são inerentes aos parâmetros de representação da garantia de ficção e literária. Mas, nem todos foram usados na indexação, pois alguns não foram importantes para os usuários das instituições pesquisadas, o que também demonstra que a garantia do usuário foi respeitada. Além disso, as outras garantias também foram consideradas importantes, pois outros elementos característicos do texto identificados foram aprovados para constituírem a representação e foram descobertos por meio do modelo de leitura documental. Portanto, o modelo fundamentado pelas garantias foi aprovado por bibliotecários escolares, que também mostraram meios para seu aprimoramento, que foram incorporados por se mostrarem importantes para a realidade de biblioteca escolar.

\section{REFERÊNCIAS}

Alves, R. C. V. (2008). Análise documental de textos lLiterários infanto-juvenis: perspectivas metodológicas com vistas à identificação do tema. (Dissertação Mestrado em Ciência da Informação). UNESP, Marília.

Alves, R. C. V. (2016). Aboutness em análise documental de textos literários infanto-juvenis: perspectivas para o aprimoramento da representação de conteúdo. (Tese Doutorado em Ciência da Informação). UNESP, Marília. 
Alves, R. C.V. (2017). Modelo de leitura documentária para indexação de literatura infantil do gênero fábula: esquemas textuais para fundamentação de estratégias metacognitivas. In M.S.L. Fujita.; D.A. de B. Neves; P.R. Dal'Evedove (Org.). Leitura documentária: estudos avançados para a indexação (pp. 133-156). Marília: Oficina Universitária.

Associação Brasileira de Normas Técnicas (1992). NBR 12676: Métodos para análise de documentos: Determinação de seus assuntos e seleção de termos de indexação. Rio de Janeiro: ABNT.

Barbosa, S., Mey, E. S. A. e Silveira, N. C. (2005). Vocabulário controlado para indexação de obras ficcionais. Brasília, DF: Briquet de Lemos / Livros.

Barité, M. (2007). La garantía literaria: vigencia y proyección teórico-metodológica. In: ENANCIB, 8, 2007, Salvador. Anais... Salvador: ANCIB. Disponível em http://www.enancib.ppgci.ufba.br/artigos/GT2--068.pdf

Barité, M. (2009). Garantía literaria y normas para construcción de vocabularios controlados: aspectos epistemológicos y metodológicos. Scire, 15(2), 13-24. Disponível em https://www.ibersid.eu/ojs/index.php/scire/article/view/ 3709

Barité, M. et al. (2010). Garantia literária: elementos para uma revisão crítica após um século. TransInformação, 22(2), 123-138.

Barité, M. (2018). Literary Warrant. Knowledge organization, 45(6).

Beghtol, C. (1986). Semantic validity: concepts of warrant in bibliographic classification systems. Library resources \& technical services, 30(02), 109-125. Disponível em https://alair.ala.org/bitstream/handle/11213/8827/lrtsv30 no2.pdf? sequence $=1 \&$ isAllowed $=y \#$ page $=3$

Beghtol, C. (1989). Access to fiction: a problem in classification theory and practice. Part I. International classification, 3, 134-140. Disponível em https://www.nomos-elibrary.de/10.5771/0943-7444-1989-3-134.pdf?download_f ull_pdf $=1$

Beghtol, C. (1994). The classification of fiction: the development of a system based on theoretical principles. Metuchen, N.J: The Scarecrow.

Beghtol, C. (1995). Domain analysis, literary warrant, and consensus: the case of fiction studies. Journal of the American Society for Information Science, 46(1), 30-44.

Boccato, V. R. C., Fujita, M. S. L. e Rubi, M. P. (2010). Estudio observacional del contexto sociocognitivo de la catalogación de materias en bibliotecas universitárias. Scire, 16(2), 103-110. Disponível em https://www.ibersi d.eu/ojs/index.php/scire/article/view/4023

Brasil. Secretaria de Educação Fundamental. (1997). Parâmetros curriculares nacionais: apresentação dos temas transversais, ética. Brasília: MEC. Disponível em http://portal.mec.gov.br/seb/arquivos/pdf/livro081.pdf

Brasil. Secretaria de Educação Fundamental. (1998). Parâmetros curriculares nacionais: terceiro e quarto ciclos: apresentação dos temas transversais. Brasília: MEC. Disponível em http://portal.mec.gov.br/seb/arquivos/pdf/ ttransversais.pdf

Coelho, N. N. (2010). Literatura infantil. São Paulo: Moderna.

Colomer, T. (2017). Introdução à literatura infantil e juvenil atual. São Paulo: Global.

D’Onofrio, S. (2007). Forma e sentido do texto literário. São Paulo: Ática.

Fiorin, J. L. (1999). Sendas e veredas da semiótica narrativa e discursiva. Delta, 15(1). Disponível em http://www.sci elo.br/scielo.php?script=sci_arttext\&pid=S0102-44501999000100009\&lng=en\&nrm=iso

Fiorin, J. L. (2014). Elementos de análise do discurso. São Paulo: Contexto.

Fiorin, J. L. (2015). Em busca do sentido. São Paulo: Contexto.

Fujita, M. S. L. (1999). A leitura do indexador: estudo de observação. Perspectivas em Ciência da Informação, 4(1), 101-116. Disponível em http://www.brapci.inf.br/_repositorio/2010/11/pdf_78c2ce7393_0012667.pdf

Fujita, M. S. L. (2003). A leitura documentária do indexador: aspectos cognitivos e linguísticos influentes na formação do leitor profissional. (Tese Livre-Docência em Análise Documentária e Linguagens Documentárias Alfabéticas). UNESP, Marília. 
Fujita, M. S. L. (2013). A representação documentária no processo de indexação com o modelo de leitura documentária para textos científicos e livros: uma abordagem cognitiva com protocolo verbal. PontodeAcesso, 7(1), $42-66$. Disponível em https://portalseer.ufba.br/index.php/revistaici/article/view/8135/5807

Fujita, M. S. L. et al. (2017). Indexação de obras de ficção em bibliotecas: avaliação e adequação do Modelo para indexação de ficção (MENTIF). Palabra clave, La Plata, 7(1). Disponível em https://www.palabraclave.fahce. unlp.edu.ar/article/view/PCe041/8869

Fujita, M. S. L., Nardi, M. I. A. e Fagundes, S. A. (2003). A observação da leitura documentária por meio de Protocolo Verbal. In G.M. Rodrigues e I.L. Lopez (Org.). Organização e representação do conhecimento na perspectiva da ciência da informação (v. 2. pp. 141-17). Brasília: Thesaurus; UNB.

Fujita, M. S. L. e Rubi, M. P. (2006). Um modelo de leitura documentária para a indexação de artigos científicos: princípios de elaboração e uso para a formação de indexadores. DataGramaZero [BRAPCI], 7(3). Disponível em http://www.brapci.inf.br/index.php/res/v/5926

Gancho, C. V. (2014). Como analisar narrativas. São Paulo: Ática.

Gregorin Filho, J. N. (2009). Literatura infantil: múltiplas linguagens na formação de leitores. São Paulo: Melhoramentos.

Gregorin Filho, J. N. (2011). Literatura juvenil: adolescência, cultura e formação de leitores. São Paulo: Melhoramentos.

Guimarães, J. A. C. e Pinho, F. A. (2007). Desafios da representação do conhecimento: abordagem ética. Informação \& informação, 12(1). Disponível em http://www.uel.br/revistas/uel/index.php/informacao/article/view/1753 $/ 1500$

Hjørland, B. (2013). User-based and cognitive approaches to knowledge organization: a theoretical Analysis of the research literature. Knowledge organization, $40(1)$.

Laipelt, R do C. F. (2015). A análise de logs como estratégia para a realização da garantia do usuário. Em Questão, 21(3), 150-170. Disponível em https://seer.ufrgs.br/EmQuestao/article/view/59806

Library of Congress Catalog. (2019?). Harry Potter and the prisoner of Azkaban: [full record book]. Washington, D.C: Library of Congress. Disponível em https://catalog.loc.gov/vwebv/holdingsInfo?searchId=23419\&recCount= $25 \&$ recPointer $=6 \&$ bibId $=4995027$

National Information Standards Organization. (2010). ANSI/NISO Z39.19-2005 (R2010): Guidelines for the Construction, Format, and Management of Monolingual Controlled Vocabularies. Baltimore, Maryland: NISO.

Oliveira, D. A e Araujo, R F. de. (2012). Construção de linguagens documentárias em sistemas de recuperação da informação: a importância da garantia do usuário. Encontros Bibli: revista eletrônica de biblioteconomia e ciência da informação, 17(34). Disponível em https://periodicos.ufsc.br/index.php/eb/article/view/1518-2924.2012v $17 \mathrm{n} 34 \mathrm{p} 17$

Personagem, a essência da narrativa. (2017). Letras de hoje, 52(2), 106-107. Disponível em http://www.scielo.br/pd f/lh/v52n2/0101-3335-letras-52-02-0106.pdf

Sabbag, D. (2017). Orientações para uso do MENTIF (Metodologia para Indexação de Ficção). In M.S.L. Fujita (Coord.). Manual de politica de indexação para as bibliotecas universitárias da Unesp (pp. 19-28). São Paulo: Unesp. Disponível em https://www.biblioteca.unesp.br/portal/arquivos/manual-politica-indexacao-2017.pdf

Silva, M. dos R. e Fujita, M. S. L. (2004). A prática de indexação: análise da evolução de tendências teóricas e metodológicas. TransInformação, 16(2), 133-161. Disponível em http://www.scielo.br/pdf/tinf/v16n2/03.pdf

Terra, E. (2014). Leitura do texto literário. São Paulo: Contexto.

Van Der Walt, M. S. (2004). Ethics in indexing and classification. In: ISKO Germany, 9th. Proceedings. Duisburg: Universität Duisburg, Germany.

Van Dijk, T. A. (2000). El estudio del discurso. In T.A. Van Dijk (Comp.).El discurso como estructura y proceso: estudios sobre el discurso I (pp. 21-65). Barcelona: Gedisa.

Van Dijk, T. A. (2004). Cognição, discurso e interação. São Paulo: Contexto. 


\section{Apêndice A - Adequações do Modelo Empírico de Leitura Documental para indexação da literatura infantojuvenil de ficção em prosa para biblioteca escolar.}

Quadro 3 - Modelo Empírico de Leitura Documental para indexação da literatura infantojuvenil de ficção em prosa para biblioteca escolar.

\begin{tabular}{|c|c|c|c|c|}
\hline \multicolumn{5}{|c|}{ Colocar a Referência do texto para indexação: } \\
\hline $\begin{array}{l}\text { PARTES DA } \\
\text { ESTRU-TURA } \\
\text { DO TEXTO } \\
\text { (coluna 1) }\end{array}$ & $\begin{array}{l}\text { CONCEI-TOS } \\
\text { OU CATEGO- } \\
\text { RIAS } \\
\text { (coluna2) }\end{array}$ & $\begin{array}{l}\text { QUESTIONAMENTOS PARA IDENTIFICAÇÃO DOS TEMAS OU } \\
\text { ASSUNTOS } \\
\text { (coluna3) }\end{array}$ & $\begin{array}{l}\text { IDENTIFI- } \\
\text { CAÇAO DE } \\
\text { TEMAS OU } \\
\text { ASSUN-TOS } \\
\text { (coluna 4) }\end{array}$ & $\begin{array}{l}\text { SELEÇÅ̃ } \\
\text { DE TEMAS } \\
\text { OU ASSUN- } \\
\text { TOS } \\
\text { (coluna 5) }\end{array}$ \\
\hline \multirow{3}{*}{$\begin{array}{l}\text { Elementos } \\
\text { preliminares } \\
\text { do texto } \\
\text { Capitulos } \\
\text { iniciais }\end{array}$} & $\begin{array}{l}\text { GÊNERO } \\
\text { TEXTUAL }\end{array}$ & $\begin{array}{l}\text { 1) Quais são os gêneros textuais? } \\
\text { Exemplos: } \\
\text { Literatura infantojuvenil } \\
\text { Literatura infantil } \\
\text { Literatura juvenil }\end{array}$ & & \\
\hline & $\begin{array}{l}\text { SUBGÊNE- } \\
\text { RO TEXTUAL } \\
\text { OU OUTROS } \\
\text { GENEROS } \\
\text { TEXTUAIS }\end{array}$ & $\begin{array}{l}\text { 2) Quais são os subgêneros ou gêneros textuais específicos? } \\
\text { Observações: essas características serão confirmadas no decorrer da } \\
\text { leitura; pode serutilizado o “Vocabuáário controlado para Indexação de } \\
\text { Obras Ficcionais" (Barbosa, Mey e Silveira, 2005), ou outro vocabulário } \\
\text { controlado com termos ficcionais para apoio. }\end{array}$ & & \\
\hline & $\begin{array}{l}\text { PERSONA- } \\
\text { GENS } \\
\text { PRINCI-PAIS } \\
\text { Quem? }\end{array}$ & $\begin{array}{l}\text { 3) Quem são os personagens principais? } \\
\text { Observações: nomes; características físicas (serelevantes); } \\
\text { caracteŕsticas psicológicas (boas e más); características sociais; o que } \\
\text { fazem e o que sentem (emoções importantes). }\end{array}$ & & \\
\hline \multirow[t]{3}{*}{$\begin{array}{l}\text { Capítulos } \\
\text { iniciais }\end{array}$} & $\begin{array}{l}\text { PERSONA- } \\
\text { GENS } \\
\text { PRINCI-PAIS } \\
\text { Quem? }\end{array}$ & $\begin{array}{l}\text { 4) Quem são os personagens principais? } \\
\text { Observações: seres ou atores que existem e participam no mundo da } \\
\text { ficção, podem ser o narrador, o herói e o vilão, se foro caso, também, } \\
\text { seres (animados, inanimados, imaginários, pessoa, animal, alguma } \\
\text { coisa etc.); Apresentam atributos para indexacão como: nomes; } \\
\text { nacionalidade (se forimportante); características físicas (se forem } \\
\text { relevantes); características psicolócicas (boas e más; sentimentos } \\
\text { importantes; ideais); características sociais (pai e fillho; empresário; } \\
\text { fazendeiro; estudante etc.). Os pers onagens carregam e apresentam } \\
\text { açôes, transformaçôes, descobertas, realizam algo e sentem emoçôes } \\
\text { importantes. }\end{array}$ & & \\
\hline & NARRA-DOR & $\begin{array}{l}\text { 5) Qual o tipo de narrador? } \\
\text { Observaçōes: verbos em primeira pessoa (narradorpersonaqem e } \\
\text { narcadortesstemunha, que vive a história, mas não é o personagem } \\
\text { principal); verbosem terceira pessoa (narrador observador que mostra os } \\
\text { fatos à medida que acontecem, e narrador onisciente que sabe até como } \\
\text { os personagens se sentem). Po deter mais queum tipo. }\end{array}$ & & \\
\hline & $\begin{array}{l}\text { ESPAÇO } \\
\text { Onde? (lugar) }\end{array}$ & $\begin{array}{l}\text { Onde aconteceu a história, em que cenário e em qual } \\
\text { ambiente? } \\
\text { Observações: composto de cenários (lugar físico: escola, casa, floresta } \\
\text { etc.) e ambientes (aspecto psicológico: chique, pobre, alegre, moderno, } \\
\text { aterrorizante, aconchegante). }\end{array}$ & & \\
\hline
\end{tabular}




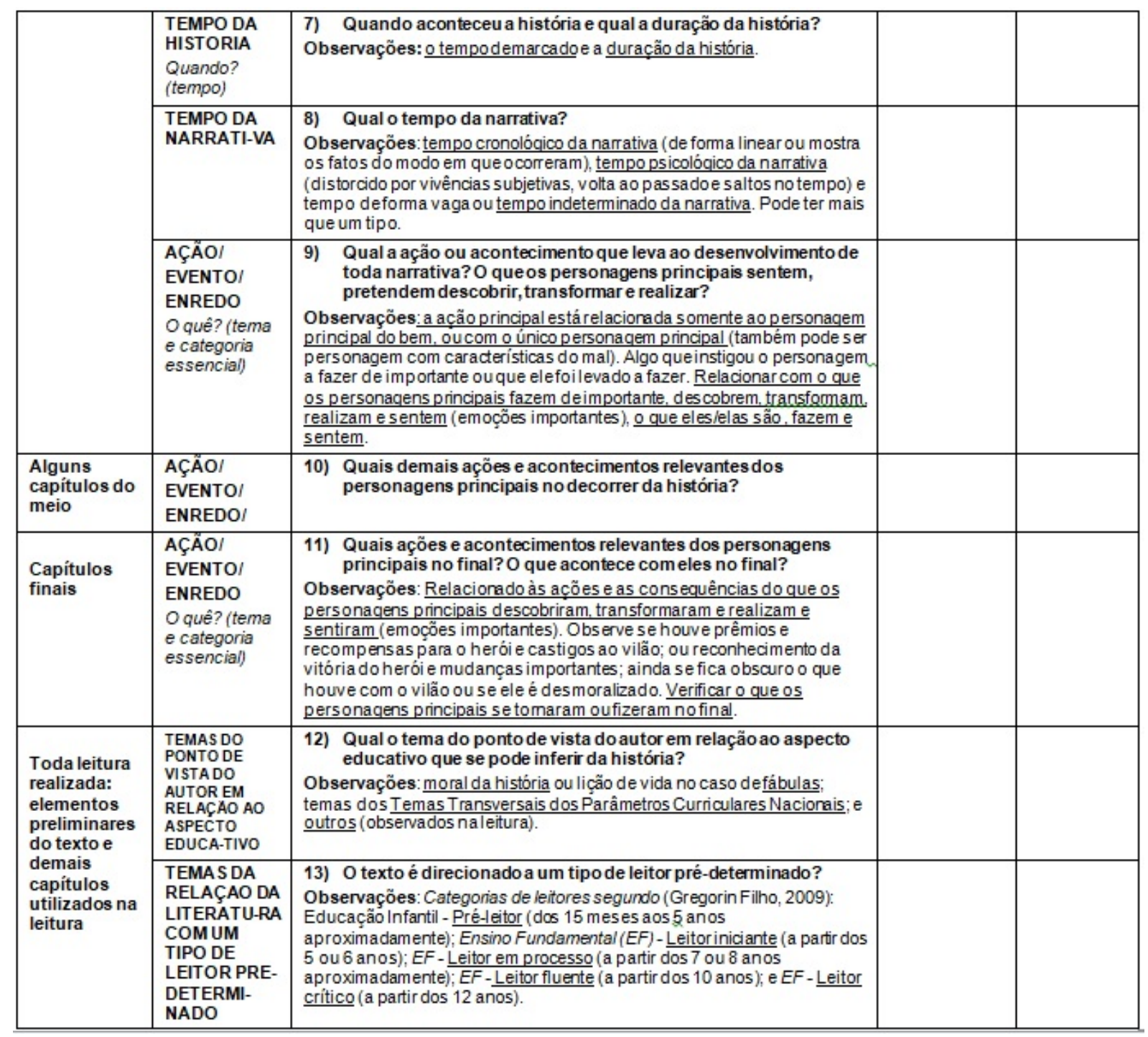

Fonte: elaborado pela autora.

\section{Apêndice B - Manual explicativo com adequações do Modelo Empírico de Leitura Documental para indexação da literatura infantojuvenil de ficção em prosa para biblioteca escolar}

A indexação da literatura infantojuvenil de ficção em prosa em biblioteca escolar é muito importante para que o usuário possa encontrar a leitura que deseja. Para isso, seus processos são embasados em garantias que fundamentam a identificação, seleção e representação de características dos textos ficcionais (garantia de ficção), isso também sobre os conteúdos do documento (garantia literária), ainda, que as necessidades de recuperação da informação por usuários sejam atendidas (garantia de uso). Este Modelo Empírico de Leitura Documental para indexação da literatura infantojuvenil de ficção em prosa para biblioteca escolar visa apoiar esses processos de indexação. As instruções para isso estão a seguir.

1 Exploração da estrutura textual da literatura infantojuvenil de ficção em prosa

Encontre no texto as suas partes básicas para leitura documental e os conteúdos: 
a) Elementos preliminares do texto (Capa; Folha de rosto; Última capa; Orelhas do livro; Apresentação ou algum elemento pré-textual; Folheto explicativo; e Sumário): gênero textual; subgênero textual ou outros gêneros textuais; personagens principais, quem são e o que fazem e sentem; b) Capitulos iniciais (os dois primeiros capítulos ou folhas iniciais, ou até encontrar a ação principal que leva ao desenvolvimento de toda a história): personagens principais; narrador; espaço; tempo da história; tempo da narrativa; ação/ evento/enredo; c) Alguns capitulos do meio (para consulta rápida e saltando trechos): ação/evento/enredo; d) Capitulos finais (dois últimos capítulos, ou folhas finais que demonstrem aspectos do final): ação/evento/ enredo; e) Toda leitura realizada das partes demarcadas (para refletir sobre temas): temas do ponto de vista do autor em relação ao aspecto educativo; temas da relação da literatura com um tipo de leitor pré-determinado.

2 Identificação de temas ou assuntos da literatura infantojuvenil para seleção de termos com base no texto e necessidades dos usuários

Observe que a estrutura textual pode se apresentar de modo padronizado de "começo, meio e fim", ou não, pois em uma história ficcional o autor pode iniciar os fatos aparentando um final e depois relembrar o começo, ou ter outros modos de apresentação. Por isso é importante entender esses aspectos, entre outros, por inferência e pressuposição. Para a indexação é importante localizar os elementos do texto para identificação de seus respectivos conteúdos:

a) Gênero textual: geralmente, em biblioteca escolar, são usados os gêneros mais gerais como: Literatura infantojuvenil; Literatura infantil; e Literatura juvenil. Exceto esses, é recomendado uso de um vocabulário controlado, ou linguagem de indexação de termos ficcionais.

b) Subgênero textual ou outros gêneros textuais: podem ser consultados no vocabulário de Barbosa, Mey e Silveira (2005), ou algum outro vocabulário, ou linguagem de indexação de termos ficcionais.

c) Personagens principais - quem?: são seres ou atores que existem e participam no mundo da ficção, podem ser o narrador, o herói e o vilão, se for o caso, também, seres (animados, inanimados, imaginários, pessoa, animal, alguma coisa etc.); Apresentam atributos para indexação como: nomes; nacionalidade (se for importante); características físicas (se forem relevantes); características psicológicas (boas e más; sentimentos importantes; ideais); características sociais (pai e filho; empresário; fazendeiro; estudante etc.). Os personagens como entidades ficcionais carregam e apresentam ações, transformações, descobertas, realizam algo e sentem emoções importantes. Também, dão sentido ao que acontece na história, pois o texto deve convencer de que tudo está ali porque o personagem faz com que as coisas aconteçam (importante relação com a ação/evento/enredo).

d) Narrador: os tipos de narrador são inferidos conforme as características de foco narrativo: verbos em primeira pessoa são do narrador personagem (narrador protagonista ou narrador personagem principal da história) e narrador testemunha, que vive a história, mas não é o personagem principal; e verbos em terceira pessoa são do narrador observador, que mostra os fatos à medida que acontecem, e do narrador onisciente, que sabe e descreve tudo na narrativa, incluindo os sentimentos dos personagens. Pode aparecer mais que um tipo de narrador.

e) Espaço - onde? (lugar): o espaço deve ser verificado por meio de cenários (lugar físico: escola, casa, floresta etc.) e ambientes (aspecto psicológico: chique, pobre, alegre, moderno, aterrorizante, aconchegante etc.); e deve ser indexado somente se for relevante na história.

f) Tempo da história - quando? (tempo): mostra o tempo demarcado (data determinada, uma unidade de tempo) e a duração da história (período de tempo), mas o que é importante para a indexação é, por exemplo, os termos que revelam esse tempo: alguns anos, uma semana, no verão, ano de 1500, tempo antigo, tempo atual, tempo futuro, saltos no tempo e história com lembranças do passado. Também, pode ser indexado somente se for relevante na história.

g) Tempo da narrativa: apresenta o tempo cronológico da narrativa (de forma linear ou mostra os fatos do modo em que ocorreram); o tempo psicológico da narrativa (distorcido por vivências subjetivas, volta 
ao passado e saltos no tempo); e tempo de forma vaga, como nos contos de fadas ou denominado de tempo indeterminado da narrativa. Podem ser apresentados mais que um tipo de tempo na narrativa do texto.

h) Ação/evento/enredo - o quê? (tema e categoria essencial): esses três termos refletem os acontecimentos da história (fatos, fenômenos naturais e sobrenaturais, situações, relacionamentos etc.). A ação/evento/enredoapresenta várias etapas, nos capítulos iniciais se tem a exposição(acontecimento que introduz ou apresenta o começo da história), que desencadeia novos fatos como consequência. Portanto, existe uma ação que é principal, na qual todas as outras estão relacionadas e que constitui o tema principal, também, essa ação ou acontecimento tem relação com o quê os personagens interagem entre si, transformam, manifestam de seu interior (emoções), descobrem e realizam. Observe se às vezes os acontecimentos do cotidiano podem estar em um segundo plano oferecendo contexto para algo mais profundo. Pois, os acontecimentos podem apresentar conflitos entre personagens, entre personagem e ambiente, ou até uma crise emocional do personagem (emoções e sentimentos). Esses acontecimentos ocorrem devido a uma situação de manipulação entre personagens, relacionada com uma transformação, quando um manipulador (geralmente o vilão ou personagem mal intencionado) tenta convencer o manipulado (herói ou personagem do bem) a fazer algo. Mas, o próprio herói ou personagem principal pode exercer a manipulação em si para buscar, conhecer, fazer ou resolver algo transformador. Alguns exemplos de manipulação: desafio, curiosidade, proposta, recompensa, tentação, pedido, bullying, ordem, ameaça, desesperança, desonestidade, sedução, provocação, preguiça, injustiça, desejo, preconceito etc. (toda persuasão que leva um sujeito/ personagem a uma reação, que tem como consequência o desenvolvimento da história). Nos capítulos do meio são apresentados o desenvolvimento de conflitos, portanto, mostram a ação/evento/enredono âmbito da complicação (que precisa ser resolvida), como também o desenvolvimento do conflito e clímax, que é o momento de maior tensão do conflito. Também, o personagem precisa de competência para realizar e transformar as situações conflituosas. $\mathrm{E}$ as demais ações que mostram o desenvolvimento da história. Nos capítulos finais ocorre a ação/evento/enredo com o desfecho, desenlace ou conclusão e a solução do conflito; final bom ou mau para os personagens principais e as consequências do que os descobriram, transformaram e realizam e sentiram (emoções importantes). Conforme o caso demonstra os resultados pragmáticos, ou seja, se para o personagem do bem (herói) houve prêmios e recompensas, além disso, se houve castigos atribuídos ao vilão ou personagem do mal. Também, consequências em âmbito psicológico para os personagens principais: se o herói obteve reconhecimento de sua vitória perante os outros ou para si, e se houve mudanças em sua personalidade; se fica obscuro o que houve com o vilão (ele foge), ou mostra sua desmoralização. E apresenta a moral da história.

i) Temas do ponto de vista do autor em relação ao aspecto educativo: esses temas podem ser relacionados com a intenção do autor de apresentar temas educativos, como a clássica moral da história em fábulas e de acordo com os Temas Transversais dos Parâmetros Curriculares Nacionais (PCNs), que podem ser ser indexados somente quando a literatura apresentar grande valorização dessas temáticas, ainda se a biblioteca escolar precisa responder a uma necessidade de informação ao usuário. Os temas transversais dos PCNs são importantes para retratar a vida cotidiana, e buscam alertar aspectos da cidadania entre os indivíduos (BRASIL, 1997, 1998).

j) Temas da relação da literatura com um tipo de leitor pré-determinado: ocorrem quando é o caso da biblioteca escolar indicar a leitura conforme alguns tipos psicológicos de leitor em relação ao tipo de texto e, assim, responder a alguma necessidade de informação do usuário. Pr exemplo, segundo Gregorin Filho (2009, p. 45-46) são: Educação Infantil - Pré-leitor (dos 15 meses aos 5 anos aproximadamente); Ensino Fundamental (EF) - Leitor iniciante (a partir dos 5 ou 6 anos); EF - Leitor em processo (a partir dos 7 ou 8 anos); EF - Leitor fluente (a partir dos 10 anos); EF - Leitor crítico (a partir dos 12 anos). A indexação, no sentido de identificar o livro voltado para um tipo de leitor pré-determinado pode contribuir para que o usuário encontre a leitura apropriada. Mas, recomenda-se que seja usada somente quando necessário, para não limitar o acesso do livro para a criança e o adolescente. 
Para a indexação com este modelo de leitura volte a consultar as instruções apresentadas, caso for necessário. Verifique a relação do texto com as colunas do quadro.

3 Algumas instruções para representação em termos de indexação de ficção

Os termos selecionados podem ser traduzidos para uma linguagem de indexação e/ou vocabulário controlado para serem representados no sistema, para fins de recuperação da informação. Os termos ficcionais devem ser indicados como tal, por exemplo: "Família - ficção", para não serem confundidos com termos científicos. Um exemplo, segundo a Library of Congress Catalog (2019?) ${ }^{5}$, é o registro bibliográfico de "Harry Potter and the prisoner of Azkaban", de J. K. Rowling, que apresenta os seguintes termos de indexação traduzidos para a Língua Portuguesa: Potter, Harry (Personagem fictício) - Ficção juvenil; Granger, Hermione (Personagem fictício) - Ficção juvenil; Escola de Magia e Bruxaria de Hogwarts (Organização imaginária) - Ficção juvenil; Bruxos - Fiç̧ão juvenil; Magia - Ficção juvenil; Inglaterra - Ficção.

Cabe ao bibliotecário escolar identificar e representar esses temas de modo padronizado, utilizando no mínimo a expressão "- ficção". Outros termos que não necessitam dessa descrição, podem ser padronizados, a critério do bibliotecário e da linguagem de indexação utilizada, por exemplo: Tempo cronológico da narrativa; Narrador observador etc.

\section{Notas}

1 Financiamento CNPq, processo no $150884 / 2018-4$.

2 Tradução nossa.

3 Tradução nossa.

4 Tradução nossa.

5 Tradução nossa. 